\title{
TOTAL CHOLESTEROL ANALYSIS FOR DIFFERENTIATING EXUDATES AND TRANSUDATES IN PLEURAL FLUIDS
}

\author{
Efelina Sutanto, Liong Boy Kurniawan, Fitriani Mangarengi \\ Department of Clinical Pathology, Faculty of Medicine, Hasanuddin University/Wahidin Sudirohusodo Hospital, Makassar, \\ Indonesia. E-mail: efelinasutanto@yahoo.com
}

\begin{abstract}
The aimed of this study is to compare the diagnostic value of pleural fluid total cholesterol and Light's criteria to determine exudate or transudate. The samples used in this cross-sectional study were pleural fluid specimens sent to the Clinical Pathology Laboratory of the Dr.Wahidin Sudirohusodo Hospital Makassar during the period of August-September 2016. Data were grouped according to the type of effusion then statistically analyzed using nonparametric Mann Whitney U-test. The result of this study showed from 55 samples, there were 22 transudates and 33 exudates. The mean total cholesterol levels of exudate is higher than transudate $(\mathrm{p}=0.006)$. By using cut-off value of total cholesterol pleural fluid $56 \mathrm{mg} / \mathrm{dL}$, it had sensitivity $72.7 \%$; specificity 78.8\%; Positive Predictive Value (PPV) $81.3 \%$ and Negative Predictive Value (NPV) $69.6 \%$ while Light's criteria had sensitivity 97\%; specificity 63.6\%; PPV 80\% and NPV 93.3\%. Pleural fluid total cholesterol level with cut-off $56 \mathrm{mg} / \mathrm{dL}$ is proposed to be used for differentiating exudate and transudate because it is easier and more simple to perform than Light's criteria.
\end{abstract}

Keywords: Pleural fluid cholesterol, Light's criteria, pleural effusion, exudate, transudate

\section{INTRODUCTION}

Pleural effusion is the accumulation of abnormal fluid in the pleural space caused by increased fluid production or reduced absorption. Pleural effusion based on its forming mechanism can be differentiated into transudates and exudates. Transudates are generated due to an imbalance between hydrostatic and oncotic pressures, whereas exudates are produced by pleural inflammatory processes or considered as a result of decreased lymphatic drainage ability. ${ }^{1,2}$

Light's criteria (1972) has become the standard method for differentiating exudates from transudates. Porcel reported that Light sensitivity is quite high (98\%). However, its specificity is less satisfactory since Light's criteria classify $25 \%$ of transudates as exudates. On the other hand, several studies have reported that total cholesterol test can be considered as an alternative in determining types of pleural effusion. $^{2,3}$ Cholesterol is a metabolite containing sterol fat found in cell membranes and circulated in blood plasma. Increased total cholesterol in exudates due to cell degeneration and vascular leakage can trigger cholesterol to enter the pleural space. ${ }^{4,5}$ Consequent- tly, this research aimed to analyze how total cholesterol analysis differentiates exudates from transudates in pleural fluid compared with Light's criteria. Results of this research then are expected to determine which analysis method is more precise and simple, thus considered as a reference for clinicians in choosing an effective and efficient test.

\section{METHODS}

This research was a cross-sectional study conducted at the Clinical Pathology Laboratory of the Dr. Wahidin Sudirohusodo Hospital in Makassar from August 2016 to September 2016. This research has been approved by the Medical Research Ethics Commission of Medical Faculty, UNHAS - RSPTN UH together with Dr.Wahidin Sudirohusodo Hospital with no.UH16060636. Samples used in this research were pleural fluid specimens examined at the Clinical Pathology Laboratory of the Dr.Wahidin Sudirohusodo Hospital. On the other hand, some pleural fluid specimens were examined by assessing total cholesterol with the colorimetric method using a chemical autoanalyzer (ABX Pentra 
400) after the patients signed informed consent. Pleural fluid specimens from patients with indefinite diagnosis then were excluded.

Next, transudative and exudative pleural effusions were determined based on a definitive diagnosis as gold standard as well as based on Light's criteria. The diagnose of malignancy, moreover, was determined based on cytology results. Meanwhile, the diagnosis of infection was establised based on pleural fluid culture and sputum smear examination. Afterwards, the diagnosis of congestive heart failure, kidney disease and liver cirrhosis was established due to physical examination and other investigations. Based on Light's criteria, exudates can be recognized if: Ratio of pleural fluid protein to serum is more than 0.5; Lactate dehydrogenase (LDH) ratio of pleural fluid protein to serum is more than 0.6: or Lactate dehydrogenase (LDH) ratio of pleural fluid is more than $200 \mathrm{U} / \mathrm{L}$.

Afterward, data collected were statistically analyzed with nonparametric test i.e. Mann Whitney U-test to reveal the difference of total cholesterol levels on exudates and transudates. Results of the MannWhitney U-test would have indicated the significant difference if a $p$-value had been less than 0.05 . The cut-off value, sensitivity and specificity of total pleural fluid cholesterol level then were determined with rived from thirty male patients (54.5\%) and twentyfive female patients (45.5\%) aged from 14 to 81 years-old. Those samples indicated that the age group mostly suffering from pleural effusion, both transudates and exudates, was the age group of $40-$ 59 years $(52.7 \%)$ as depicted in Table 1.

Table 1. Characteristics of pleural effusion samples at the Dr. Wahidin

\begin{tabular}{cccc}
\hline \multirow{2}{*}{ Variables } & \multicolumn{2}{c}{ Types of pleural effusion } & \multirow{2}{*}{$\begin{array}{c}\text { Total } \\
(n=55)\end{array}$} \\
\cline { 2 - 3 } & $\begin{array}{c}\text { Transudates } \\
(n=22)\end{array}$ & $\begin{array}{c}\text { Exudates } \\
(n=33)\end{array}$ & \\
\hline Sex & & & \\
$\quad$ Male & $10(45.5 \%)$ & $20(60.6 \%)$ & $30(54.5 \%)$ \\
$\quad$ Female & $12(54.5 \%)$ & $13(39.4 \%)$ & $25(45.5 \%)$ \\
Age (years old) & & & \\
$<20$ & $0(0 \%)$ & $1(3 \%)$ & $1(1.8 \%)$ \\
$20-39$ & $3(13.6 \%)$ & $8(24.2 \%)$ & $11(20 \%)$ \\
$40-59$ & $11(50 \%)$ & $18(54.6 \%)$ & $29(52.7 \%)$ \\
$\geq 60$ & $8(36.4 \%)$ & $6(18.2 \%)$ & $14(25.5 \%)$ \\
\hline
\end{tabular}

Moreover, those pleural effusion samples showed that there were significant differences between exudates and transudates in almost all parameters of Light's criteria, except in the parameter of total serum protein as illustrated in Table 2.

Furthermore, based on the diagnosis of those fiftyfive pleural effusion samples, there were twentytwo transudative effusion samples (40\%) and thirty-

Table 2. Characteristics of pleural effusion samples based on the laboratory parameters of Light's criteria

\begin{tabular}{|c|c|c|c|}
\hline \multirow[b]{2}{*}{ Variables } & \multicolumn{2}{|c|}{ Types of pleural effusion } & \multirow[b]{2}{*}{ P-value } \\
\hline & $\begin{array}{c}\text { Transudates }(n=22) \\
\text { Mean } \pm \text { SD }\end{array}$ & $\begin{array}{c}\text { Exudates }(n=33) \\
\text { Mean } \pm \text { SD }\end{array}$ & \\
\hline \multicolumn{4}{|l|}{ Pleura fluid } \\
\hline Total protein (g/dL) & $2.86 \pm 1.59$ & $4.38 \pm 1.92$ & 0.003 \\
\hline LDH (U/L) & $192.77 \pm 207.05$ & $2501.79 \pm 4292.95$ & 0.000 \\
\hline \multicolumn{4}{|l|}{ Serum } \\
\hline Total protein (g/dL) & $5.88 \pm 1.42$ & $5.95 \pm 1.05$ & 0.686 \\
\hline LDH (U/L) & $472.32 \pm 437.59$ & $1719.33 \pm 2756.85$ & 0.000 \\
\hline \multicolumn{4}{|l|}{ Ratio } \\
\hline Total pleural protein/serum & $0.49 \pm 0.23$ & $0.72 \pm 0.26$ & 0.001 \\
\hline LDH pleura/serum & $0.38 \pm 0.12$ & $1.05 \pm 2.02$ & 0.000 \\
\hline
\end{tabular}

Receiver Operating Characteristic (ROC) curve. Meanwhile, the sensitivity, specificity, Positive Predictive Value (PPV) and Negative Predictive Value (NPV) of the pleural fluids using the total cholesterol analysis and Light's criteria towards definitive diagnosis were determined using $2 \times 2$ tables.

\section{RESULT AND DISCUSSION}

There were fifty-five pleural fluid samples de- three exudative effusion samples (60\%). The transudative effusions were mostly found in kidney disease $(21.8 \%)$, whereas the exudative effusions were mostly found in malignancy (34.5\%) as shown in Table 3. Similarly, Khaerani et al., ${ }^{6}$ also found that malignancy was the most common cause of pleural effusion (42.8\%), followed by pulmonary tuberculosis $(42 \%)^{6}$

In those thirty-three samples of exudative 
pleural effusion, there were nineteen samples in patients with malignancies of lung tumors, breast carcinoma, malignant lymphoma and metastatic coli tumors. Meanwhile, fourteen samples were found in patients with infectious diseases, nine of whom suffered from para-pneumonia (caused by Staphylococcus aureus, Staphylococcus haemolyticus, mythic Streptococcus, Pseudomonas aeruginosa, Enterococcus faecalis and Klebsiella pneumonia based on cultured pleural fluid results) and five of whom suffered from pulmonary tuberculosis. In malignant processes, tumor cells actually can spread along parietal pleural membranes and then clog intrapleural lymphatic flow.

Tumor cells can also stimulate the release of chemokines that increase the permeability of the pleural membranes and blood vessels resulting in increased total cholesterol levels in effusion formed in the pleural cavities. ${ }^{7,8}$

On the other hand, pleural effusions caused by para -pneumonia are usually associated with pneumonia

Table 3. Distribution of samples based on disease diagnosis

\begin{tabular}{ll}
\hline Diagnosis & $\mathbf{n}(\%)$ \\
\hline Transudative effusion & $22(40)$ \\
\hline Congestive heart failure & $8(14.5)$ \\
Kidney disease & $12(21.8)$ \\
Hepatic cirrhosis & $2(3.7)$ \\
\hline Exudative effusion & $33(60)$ \\
\hline Malignancy & $19(34.5)$ \\
Infection & $14(25.5)$ \\
\hline
\end{tabular}

bacteria, lung abscess, or bronchiectasis. Pleural effusions triggered by bacterial inflammation can also activate neutrophils to damage the endothelium, which releases oxygen metabolites, granular constituents and membrane phospholipase products, thereby increasing capillary permeability. Next, extravascular lung fluid rescue increases the interstitial-pleural pressure gradients, thereby inducing fluid from the mesothelium cells into the pleural cavities leading to the formation of pleural effusion. ${ }^{9}$ Total cholesterol levels in exudative pleural effusion samples were between $20.79-168.08 \mathrm{mg} / \mathrm{dL}$ with a mean value of $78.24 \pm 36.06 \mathrm{mg} / \mathrm{dL}$. Meanwhile, total cholesterol levels in transudative pleural effusion samples were between $10.45-131.57 \mathrm{mg} / \mathrm{dL}$ with a mean value of $51.05 \pm 38.46 \mathrm{mg} / \mathrm{dL}$. Besides this, the results also showed that there was a significant difference in total cholesterol levels between the exudative and transudative pleural effusion samples with a $p$ value of $0.006(p<0.05)$ as depicted in Table 4.

Like the results of this research, a research conducted by Hamal et al., ${ }^{7}$ in Pakistan showed that total cholesterol level was higher in exudative pleural fluid as much as $1.92 \pm 0.75 \mathrm{mmol} / \mathrm{L}$, while in transudative pleural fluid it was only $0.53 \pm 0.28 \mathrm{mmol} / \mathrm{L}$. The increased total cholesterol level in the exudates can be

Table 4. Average of total cholesterol levels in pleural fluid based on types of effusion

\begin{tabular}{lccc}
\hline Variables & \multicolumn{2}{c}{ Types of pleural effusion } & \\
\cline { 2 - 3 } & $\begin{array}{c}\text { Transudates } \\
(\mathbf{n}=\mathbf{2 2}) \\
\text { Mean } \pm \text { SD }\end{array}$ & $\begin{array}{c}\text { Exudates } \\
(\mathbf{n}=\mathbf{3 3})\end{array}$ & P-value* \\
& Mean \pm SD & \\
\hline $\begin{array}{l}\text { Total cholesterol in } \\
\text { pleural fluid } \\
(\mathrm{mg} / \mathrm{dL})\end{array}$ & $51.05 \pm 38.46$ & $78.24 \pm 36.06$ & 0.006 \\
\hline
\end{tabular}

*Mann Whitney $U$ test $\mathrm{p}<0.05$; significant

triggered by inflammation, infection, or malignancy causing cell degeneration and changes in pleural membrane permeability, leading to an increase in vascular permeability and vascular damage resulting in vascular leakage that causes cholesterol to enter the pleural cavities. ${ }^{7}$

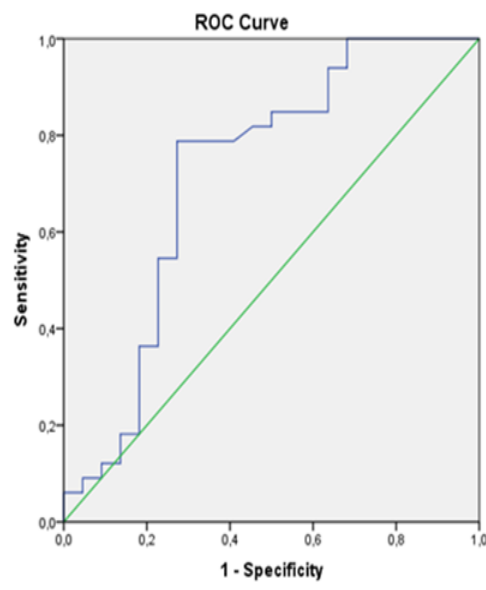

Figure 1. ROC curve of total pleural fluid cholesterol 
The cut-off value of total pleural fluid cholesterol was determined using ROC curve. The cut-off value obtained was $56 \mathrm{mg} / \mathrm{dL}$ with the sensitivity value of $78.8 \%$ and the specificity value of $72.7 \%$ (see Figure 1). Meanwhile, the sensitivity and specificity of total pleural fluid cholesterol were determined with the cut-off value of $56 \mathrm{mg} / \mathrm{dL}$ towards the definite diagnosis using $2 \times 2$ tables. The sensitivity value obtained was $78.8 \%$, while the specificity value was $72.7 \%$. Besides this, the results also showed that the PPV was $81.3 \%$, while the NPV was $69.6 \%$ as illustrated in Table 5.

Table 5. Determination of transudates and exudates based on disease diagnosis,

\begin{tabular}{cccc}
\hline \multirow{2}{*}{$\begin{array}{c}\text { Total pleural } \\
\text { fluid cholesterol }\end{array}$} & \multicolumn{2}{c}{$\begin{array}{c}\text { Types of pleural effu- } \\
\text { sion }\end{array}$} & Total \\
\cline { 2 - 3 } & Exudates & $\begin{array}{c}\text { Transu- } \\
\text { dates }\end{array}$ \\
\hline Exudates & 26 & 6 & 32 \\
Transudates & 7 & 16 & 23 \\
Total & 33 & 22 & 55 \\
\hline
\end{tabular}

Table 6. Determination of transudates and exudates based on disease diagnosis and Light's criteria

\begin{tabular}{cccc}
\hline \multirow{2}{*}{ Light's Criteria } & \multicolumn{2}{c}{ Types of pleural effusion } & Total \\
\cline { 2 - 3 } & Exudates & Transudates & \\
\hline Exudates & 32 & 8 & 40 \\
Transudates & 1 & 14 & 15 \\
Total & 33 & 22 & 55 \\
\hline
\end{tabular}

The sensitivity and specificity of Light's criteria were determined to diagnose exudates by using $2 \times 2$ tables. The results showed that the sensitivity of Light's criteria was $97 \%, 63.6 \%$ for its specificity, 80\% for PPV and 93.3\% for NPV as shown in Table 6.

Based on the results of this research, the sensitivity of the Light's criteria was $97 \%$, better than the sensitivity of the total pleural fluid cholesterol assessment (78.8\%). However, the specificity of the total pleural fluid cholesterol assessment was $72.7 \%$, higher than the specificity of Light's criteria (63.6\%) as depicted in Table 7.

Unlike the results of this research, a research conducted by Dhandapani et al., ${ }^{10}$ using a lower cut-off value of total pleural fluid cholesterol (53 mg/dL) found that the sensitivity and specificity of total pleural fluid cholesterol in fifty-three samples were
91.2\% and $94.7 \%$, higher than the sensitivity and specificity of Light's criteria, $78.6 \%$ and $90.9 \%{ }^{10}$

Table 7. Sensitivity and specificity of total pleural fluid cholesterol (cut-off $=56.02 \mathrm{mg} / \mathrm{dL}$ ) and Light's criteria

\begin{tabular}{lcc}
\multicolumn{1}{c}{ Variables } & $\begin{array}{c}\text { Sensitivity } \\
(\mathbf{\%})\end{array}$ & Specificity (\%) \\
\hline $\begin{array}{l}\text { Total pleural fluid choles- } \\
\text { terol } \\
\text { Light's criteria }\end{array}$ & 78.8 & 72.7 \\
\hline
\end{tabular}

\section{CONCLUSION AND SUGGESTION}

The results of this research showed that the cholesterol levels in exudates were higher than those in transudates. The results of this research also revealed that although the sensitivity value of Light's criteria was higher, the total cholesterol analysis had a better specificity for pleural fluid. Therefore, the total cholesterol analysis could be used to differentiate exudates from transudates. The total cholesterol analysis could also easily determine the types of pleural effusion since it was only based on the cut-off value. In addition, the total cholesterol analysis was considered as a simpler method since it used only one parameter than Light's criteria requiring four parameters. Nevertheless, it is recommended to conduct a further research with larger sample quantities and more rigorous sample criterion selection so that the total cholesterol can be considered as one of the standard parameters in pleural fluid analysis.

\section{REFERENCES}

1. Hardjoeno, Fitriani M. Tes dan Interpretasi cairan pleura dalam substansi, dan cairan tubuh. Edisi Baru. Makassar, lambaga Penerbitan Universitas Hasanuddin, 2011; 67 84.

2. Light RW. Pleural diseases. $5^{\text {th }}$ Ed., Baltimore, Lippincott Williams and Wilkins, 2007; 74-99.

3. Porcel JM. Identifying misclassified by Light's criteria. Current Opinion in Pulmonary Medicine, 2013; 19(4): 362-7.

4. Patel AK, Chaudhury S. Combined Pleural Fluid Cholesterol and Total Protein in Differentiation of Exudates and Transudates. The Indian Journal of Chest Diseases and Allied Sciences, 2013; 55(1): 21-24.

5. Fagere MO. Diagnostic Utility of Pleural Effusion and Serum Cholesterol, Lactic Dehydrogenase and Protein Ratios in the Differentiation between Transudates and Exudates. AIMS Medical Science, 2015; 3(1): 32-40. 
6. Khairani R, Syahruddin E, Partakusuma LG. Karakteristik Efusi Pleura di Rumah Sakit Persahabatan. Jurnal Respiratologi Indonesia. 2012; 32(3): 155-160

7. Hamal AB, Yogi KN, Bam N, Das SK. Pleural Fluid Cholesterol in Differentiating Exudative and Transudative Pleural Efussion. Pulmonary Medicine, 2013; 2013(2013): 1-4, Article ID 135036, http:// dx.doi.org/10.1155/2013/135036.
8. Light RW. Disorders of The Pleura and Mediastinum in Harrisons's Pulmonary and Critical Care Medicine. $17^{\text {th }}$ Ed., San Fransisco, McGraw Hill Medical, 2010; 215-9.

9. Sahn SA. Diagnosis and Management of Parapneumonic Effusions and Empyema. Clinical Infectious Disease Journal. Charleston. 2007; 45(11): 1480-6.

10. Dhandapani S, Reddy S, Rajagopalan R. Differentiating Pleural Effusions: Criteria Based on Pleural Fluid Cholesterol. Eurasian Journal Pulmonology. Chennai. 2016; 18: 76-9. 